\title{
State Management of Labor and Education Services Markets in Ukraine
}

\author{
Baydetskyy Petro \\ State Employment Service in Zbaraz \\ Ukraine \\ e-mail:baydetsky@gmail.com
}

\begin{abstract}
The aim of the study is to identify issues in employment of people in different categories. Analysis of the organization of the public administration to ensure appropriate conditions for effective search of job applicants and provide businesses according to their needs with proper level of employees' preparation in today's job market is done. Ways to improve the work of state bodies in the sphere of employment of citizens to better protect their rights on the labor market and development of social - economic situation in the country are identified.
\end{abstract}

Keywords: labor market, educational services market, state government, Ukraine

JEL classification: J21, H75, P2

\section{INTRODUCTION}

Requirements for workers in today's world are constantly increasing. The labor market is influenced by various factors, and is constantly transforming. One of the factors of the successful employment is the level of education, professional qualities of the applicant, and working experience in the specialty. Within the crisis in the global economic system, which had a great influence on the international, national and local labor market, the supply of jobs has declined or has undergone structural changes and thus the chances that a person with a certain level of education and work experience to find decent employment significantly decreased.

Analysis of this issue shows that the problem of providing the candidates with decent jobs, and economic entities with human resources of appropriate quality, the formation of which is to be ensured by the education system in many countries, particularly in Ukraine, at the present stage of the crisis, causes the relevance and practical importance of the chosen topic of research to find ways to improve governance in these areas.

The main objects of study are the active position of the candidates for the job - not occupied positions (working places) which can be occupied by a person; the labor market - a system of legal, social, labor, economic and institutional relations that arise between persons seeking employment, workers, trade unions, employers and their organizations, public authorities in meeting the workers' needs in employment, and employers - in hiring employees in accordance with the current law. Also - activity of subjects engaged in vocational training - the acquisition and improvement of professional knowledge and skills of individuals 
in accordance with the capabilities, providing an appropriate level of professional qualification for professional activity and competitiveness on the labor market; activity of state bodies in state regulation of the labor market - the formation and implementation of state policy in the field of employment in order to create conditions for full and freely chosen productive employment and social protection in case of unemployment, and providing productive employment that allows to provide effective social production and meet the needs of the employee at least at the level of the legislation guarantees.

The stated objective of the study is (1) to analyze the factors affecting the effective search of candidates and (2) to identify the issues in this field, (3) to study the mutual influence of the education system and labor market; systems analysis of the interaction of job applicants, employers, institutions engaged in training, and public authorities in today's labor market, (4) to develop and justify proposals for the improvement of work in the area of providing people in Ukraine with adequate education and work, and all sectors of the economy - with proper workforce.

\section{FUNCTIONS OF THE STATE EMPLOYMENT SERVICE}

State Employment Service is the main subject of state regulation of the labor market and consists of State Employment Center, Employment Center of the Autonomous Republic of the Crimea, Kyiv and Sevastopol city, regional, city districts', city and small towns' employment centers, centers of organizing professional training of unemployed population, centers of vocational guidance for the population, inspections of monitoring compliance with the legislation on employment (Figure 1).

Activities of the State Employment Service is conducted by the Ministry of Social Policy, local state administrations and local self-government. The structure of the public employment service also includes education institutions of training of unemployed people, information-data centers, territorial and specialized employment agencies, rehabilitation centers for people, companies, institutions and organizations under the Service. At the local level, these functions are entrusted to employment centers of the baseline.

According to the functions-orientated structure of employment centers of local (basic) level their main task is determined as - facilitating the employment of unemployed people and helping employers to fill vacancies. Therefore, the main role in their structure is played by the unit of employment and interaction with employers. This division is responsible for coordination with employers, also works with information on job vacancies. Naturally, in those employment centers, where staff quantity does not allow to create similar departments, performance of these functions rely on specific specialists.

Thus, the executive authorities, implementing state policy in the field of employment and labor migration, which are currently implemented in the system of the State Employment Service of Ukraine, have necessary human resources and methodological support for the implementation of effective labor market policies and cooperation with departments of the Ministry of Education and Science, Youth and Sport of Ukraine, which are education departments and offices of public administrations in the educational market. Negative trends in this socio - economic sphere indicate lack of prediction and prevention of negative events and absence of appropriate management decisions, based on research, that lead to negative effects on the national labor market, and outstanding and unpredicted migration process. 


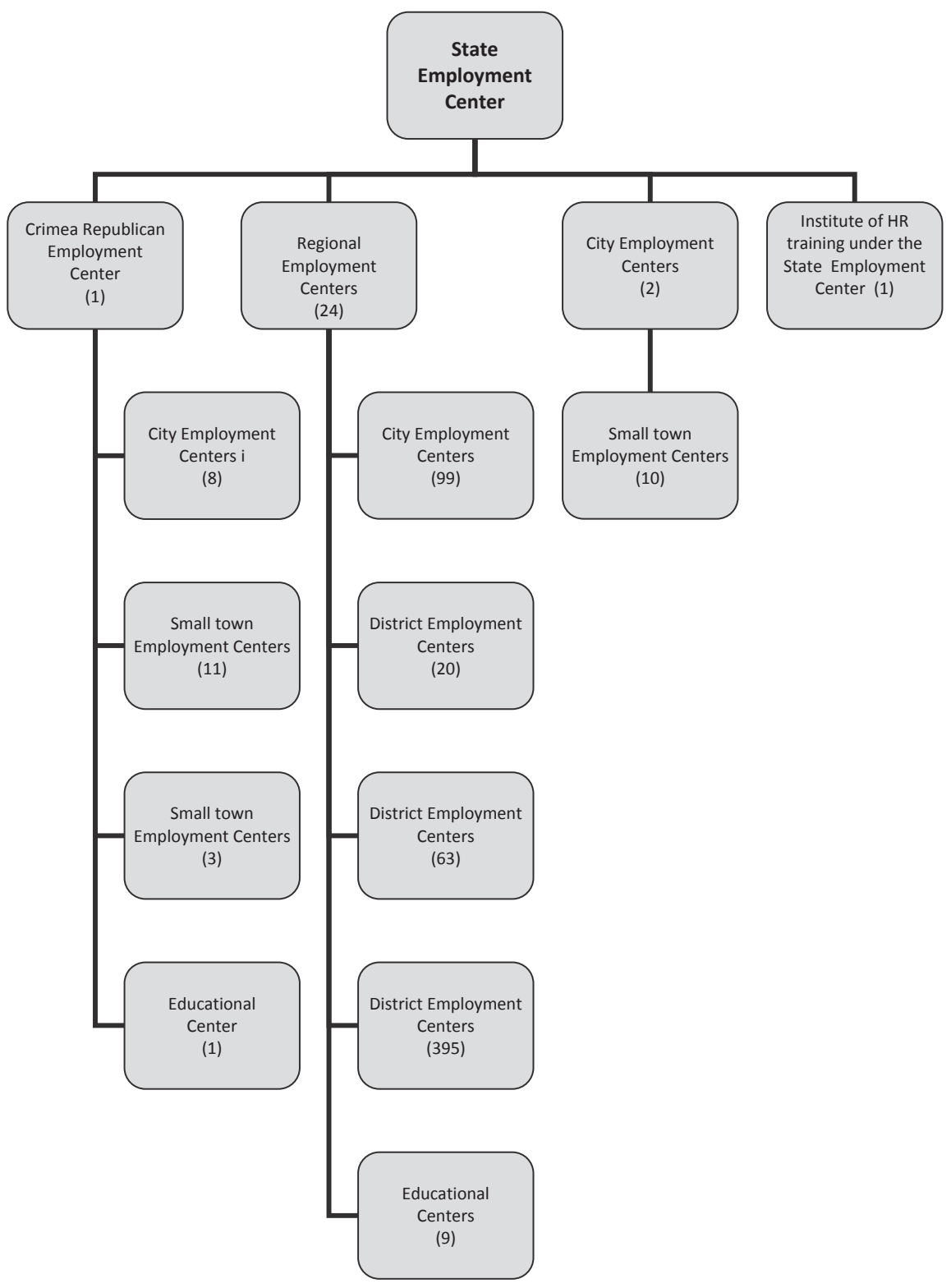

Figure 1. Structure of the State Employment Service [11].

Source: WEB - портал „Інформаційне агентство „Українські Новини” // http://ukranews.com . - 2012. - 30 листопада. 


\section{THE CURRENT LABOR MARKET OF UKRAINE}

At the present stage of development of Ukraine's labor market has many problems and contradictions. Mostly, problems with employment are experienced by people of different categories, and one of these groups are citizens aged 17-26 years. Every year in Ukraine there is fixed about $18 \%$ of unemployed youth (over 200,000 people), the cause of unemployment is the problem of finding a job after graduation from higher and vocational-technical schools (Marshavin, 2010).

Unemployment is one of the main indicators of economic development of the country. Its level reflects the situation in the financial sector and industry, and most importantly - the social sphere. In Ukraine, the unemployment rate calculations are carried out according to the International Labor Organization methodology, and they show that the situation is improving now. Thus, in the first quarter of 2012 the index was $8.4 \%-0.3$ per cent less than last year. At the same time, according to the State Statistics Committee of Ukraine data, during that same first quarter of the year the unemployment rate rose to 0.5 percent (from $7.9 \%$ at the end of 2011).

According to ILO calculations, there was 1,845 million of unemployed in that period in Ukraine with a population of 45.6 million, and it is only the officially registered unemployed people. Thus the proportion of jobs (the share) with the minimum wage is $26 \%$, in $60 \%$ of the regions the situation is much worse. Most employers put stringent requirements for professional component of the candidates for employment, including the work experience, while offering a minimum payment. Prolonged recovery from the crisis, but rather its endless waves, continued to reduce demand in the labor market - until May of this year there were only 444 thousand of them in the database of the State Employment Service (26 thousand less than in the same period of 2011). Almost a third part of the vacant jobs were concentrated in Kiev, Donetsk, Dnipropetrovsk and Kharkiv regions. That is not an easy, despite the optimistic report of the ILO, situation. To eliminate the problem, which is particularly painful in the segment of the young workforce, there is needed an economic growth, which is difficult to expect in the nearest future (http://ukranews.com, 2012).

According to the data of a popular HR portal www.hh.ua, there is a traditional, but a significant imbalance on Ukraine's labor market. The leader of the labor market is the capital, offering over half of all jobs (58\%). Other regions are following with a large margin. In general, the five most active regions are traditionally - Donetsk, Dnepropetrovsk, Kharkov, Odessa, Lviv regions.

The western regions are mainly located at the bottom of the list, while in the eastern industrial regions much more work is offered. Thus, a vacancy in the eastern part of the country is $30 \%$ out of the total, in the western - only $6 \%$.

Rating of the most sought-after specialties, according to the portal data, remains unchanged. By a large margin there leads a sales sphere and information technologies. Among the top 5 areas there were also marketers, financiers and bankers. It is not easy to find jobs for civil servants and experts in the field of security.

The most attractive working conditions traditionally are offered by big international corporations and companies working in the field of distribution and trade.

Despite the high wages at the top segment of the market, there is a big difference between the maximum and the average wage $-3-5$ thousand hryvnyas and 1-1.5 thousand (respectively).

Among the most popular in Ukraine there are experts in the field of insurance, information technology, representatives of working specialties, salesmen, experts in the field of automobile business, doctors. The market is the most saturated with young specialists and executive staff, lawyers and accountants.

That is how the labor market of Ukraine looks, which improvement is of the big concern of the government - the Cabinet of Ministers developed a new version of the draft Law "On Employment". Trade unions sharply criticized the initiative, saying that the essence of this document is only in re-subordination of the Fund of insurance against unemployment, but does not solve the problem at its root. Meanwhile the labor 
market exists as if in a parallel world - employers offer some jobs, unemployed, in turn, look for other jobs with different parameters (http://ukranews.com, 2012).

A free economy, that offers freedom of choice, confronts young people with the problem which solution depends on the state regulation of the economy. These factors primarily affect the development of labor market in Ukraine (Lastovetskyy, p. 24, 2003).

Thus, F. R. Filippov defines youth as a large social group that has specific social and psychological qualities, defined both by age-related characteristics of young people and by the fact that their socio-economic and social-political position, their spiritual world are in a state of forming (http://dcz.gov.ua, p. 458, 2012).

$\mathrm{N}$. Chernysh defines youth as socially differentiated socio-demographic community, which is characterized by specific physiological, psychological, educational, cultural - educational and other features that characterize its bio - social maturation as an exercise of expression of the internal energy and essential social skills.

The youth, in author's opinion, therefore is a specific community as its essential characteristics and features, unlike members of other age groups, are in a state of formation and development, the essence of youth and its main manifestation of social quality is a measure of the achievement of social subjectivity, the degree of assimilation of social relations and innovation activity (Global Employment Trends for Youth 2012, p.178).

The level of youth unemployment is significantly higher than the average among population in all countries with a market economy, and it has an objective explanation (Fig. 2.). Youth - is the stage when a person moves from a childhood to adulthood, from parental care - to creating their own family, from learning - to economic activity, and thus it is at this period that the youth is searching for the first job and "suitable" work, and often there are breaks in employment (Golos Ukrainy, 2012).

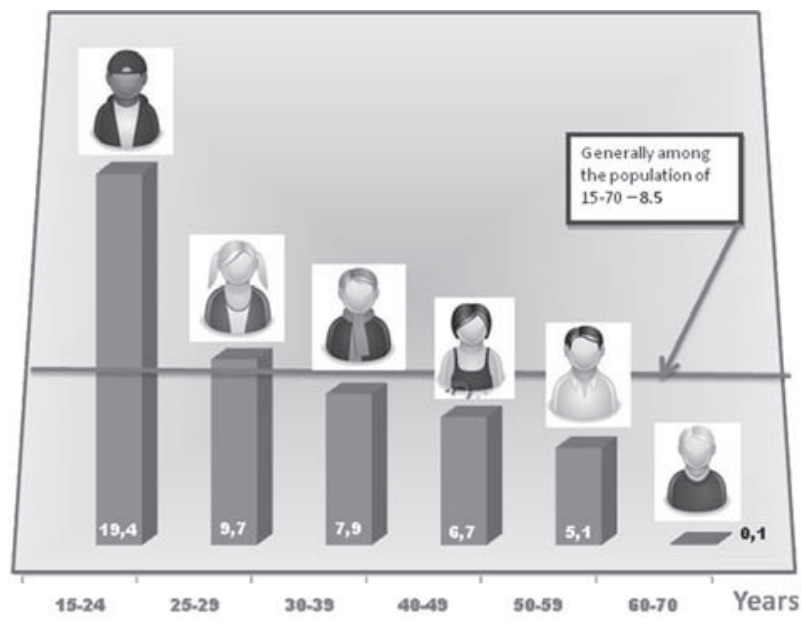

Figure 2. Unemployment rate in different age groups (according to the ILO methodology) in the first semester of $2011, \%$ [12]

Source: Закон України «Про зайнятість населення» // Голос України від 18.08.2012 . - № 153-154

One of the main factors in the entering of the youth into social processes is the integration into employment and economic activity. The success of this process depends on many psychological characteristics, values of young people and the ability of the government to effectively regulate relations in the 
labor market. Significant influence is done by the condition of the local labor market, macroeconomic factors, and other factors.

One of the main problems of youth's employment in the labor market, in our opinion, can be considered:

- lack of awareness of young people about the needs of the modern labor market;

- demands for the experience and training of young professionals by employers that do not match the realities of modern education;

- dis-match between high requests of youth for wages and decent work opportunities provided by employers.

To explore young people about the needs of the modern labor market the Departments and officials of the basic centers are conducting PR - campaigns, explanatory and information activities on web-resource of the State Employment Centers, other public authorities and social partners, on radio and in print media.

The Department of interaction with employers together with specialists of other departments organize seminars and meetings with employers, where the information and explanation of the importance of youth employment, the value of social - responsible business and motivational activities (workshops, commissions, roundtables, etc.) is given, which make it possible to employ young people on reserved and subsidized jobs, including providing subsidies to employers for young people who received college or vocational - technical education, when it is their first job.

To form the youth's adequate attitude to the realities of the labor market on wages and decent working conditions there are conducted preventive measures, guidance and information, including the information on prevention of youth unemployment spread among schoolchildren.

On the basis of the Law of Ukraine "On providing young people who received higher or vocational education with the first job offering subsidies to employers", 6 graduates of HEIs and vocational schools who do not have work experience got their first job. In 2012, the following subsidized jobs are planned to be hired by eight graduates of vocational and higher education establishments. To do this, the state budget provided 36.6 thousand hryvnyas.

Also, to improve the situation of youth employment on 01.01.2013 a new version of the Law of Ukraine "On Employment" enters into force, which provides support for young people with first job and the introduction of incentives for training in enterprises, institutions and organizations regardless of ownership, type of business and management, individuals who use hired labor, to young people who are studying.

Focus on youth employment by the Employment Service caused by the need to implement measures to prevent youth unemployment. In the system of state employment service there is the whole range of measures used to improve employment of young people in Ukraine, but there also should be made permanent search and reasonable suggestions offered for finding the ways to improve work in this area.

We believe that there should be an opportunity to attract young people to discuss the text of the Programs on region employment, their development and implementation. In particular, students in higher education institutions, students of vocational-technical and general-education institutions, representatives of youth organizations in their research works, diplomas and other creative projects may offer ways to improve the situation of youth unemployment, thus the Programs on regional employment can include their propositions, position, needs and aspirations, and young people as a result of studies of the labor market, form a real value orientation and vision of themselves on the job market.

To promote effective dialogue between young people and employers and adequate mutual vision of the realities of the labor market there should be prepared regular meetings of area employers and young people with the support of Zbarazh regional employment center, the Department of Education of Zbarazh district administration and other government agencies, Zbarazh district center of social services for families, children and young people and other stakeholders, where employers provide information about their needs 
and expectations for future employees about current vacancies, vacancies on the regional labor market, the outlook for professions (specialties), which should be selected when choosing a school.

Continuation and finding ways to improve practices of media companies both in traditional media and in electronic ones, and during a direct contact with individual consultants personally with young people during events, especially in schools and rural areas. One way to improve the situation on the labor market and the education market while adapting the national economy to contemporary processes of globalization, which are rapidly taking place, is the policy of the European and global integration.

Within the situation of integrational transformation of the economy of Ukraine the need of improvement of state regulation of the labor market has increased. At the same time there occurred the problem for the government of finding its place in the international division of labor. Analysis of the impact of economic globalization on national labor markets and prediction of such interactions will help to identify areas of regulatory activities of state authorities in Ukraine taking into account both the local workforce and capacity of the national system of education, prospects and threats from potential demographic and migration processes.

Due to integration activities, an example of which is the Bologna process, there is and adapting of education level of the applicants for jobs, productivity, wages alignment, harmonization of social and labor rights of workers, coordination of regulatory measures on the labor market, which leads to production of supranational labor market, characterized by free movement of labor, mutual influence of education, social - psychological factors, the demand for human resources. This new joint labor market has its own natural mechanisms and regulation.

Reform of state regulation of the labor market in Ukraine's integration into the European Union must take place towards the implementation of relevant legislation aimed at adapting to the new environment of cooperation with relevant entities of a common European labor market.

Despite the actions of public authorities in Ukraine there are a number of factors that affect the national labor market and its adaptation to global changes. They are: an imbalance of the structure of labor supply and demand for vocational qualification characteristics, significant informal employment, and complicated demographic situation.

\section{CONCLUSIONS}

The analysis of the status and prospects of the labor market in Ukraine under the conditions of integrative transformation shows several negative factors that need to be overcome. One of the most important negative factors is the discrepancy between the structure of preparing labor force and the needs of the labor market, indicating a lack of state regulation in the field of education. This problem is recognized and the state takes measures aimed at adapting the education system to the changing needs of the modern labor market, but the existence of such a problem for a long time is a sign of lack of effectiveness of public policy in education.

A significant backlog from the countries - members of European Union in the average level of wages is also a stimulus to immigration aspirations and outflow of qualified workers. Another factor that is recognized by the state, but not yet implemented an effective mechanisms for its regulation, is an internal regional imbalance between supply and demand in the labor market (high level of unemployment in the western and southern regions of the country) combined with greater demand and higher wages in the central and eastern regions and the low level of intra-regional migration. Also one of the factors of the negative impact is difficult demographic situation in the European Union and Ukraine, which requires a balanced policy in this area. 
Thus, there is a need for rapid use of a systematic approach to develop a system of measures aimed at adapting the labor market and the education market to new conditions of European integration and globalization of Ukraine.

Besides the problematic situations in the labor market caused by the adaptation of young people during the transition period of moving from a system of training to professional development, and issues of global transformations and crises, that are changing labor markets and setting new requirements for the state governance in employment, migration and education, there are a number of factors that are determined and which receive an attempt to be answered in the new Law of Ukraine "On Employment", which was signed by the President of Ukraine on July 5, 2012, and comes into force on 1 January 2013. Unfortunately, despite the date of entry into force of this law, there is no subordinate legislation that would clearly define mechanisms of the effects on the labor market and related areas, such as education market. In particular, the new Law of Ukraine has quite a progressive Article 30 "Capacity to improve competitiveness of citizens aged over 45 years," which should solve the issue of employment of one more complex age population. It states that persons older than 45 years with the insurance period of at least 15 years are eligible before achieving retirement age, established by Article 26 of Law of Ukraine "On Mandatory State Pension Insurance", for getting once a voucher to maintain their competitiveness through training, specialization, training for the professions and specialties of priority economic activities.

Choice of profession (specialty) from an approved list, form and place of study is done by the individuals themselves. Payment of voucher is done at the expense of the Fund of Obligatory State Social Insurance of Ukraine in case of unemployment, based on its financial capacity. The issuance of the vouchers by the territorial bodies of the central executive body that implements the state policy in the field of employment and labor migration, and list of professions, specialties and areas of training, for training which may be issued a voucher, is approved by the Cabinet of Ministers of Ukraine. The procedure of issuing vouchers and a list of occupations for training is not approved yet, which is an evidence of a lack of systematic state policy in this area.

\section{REFERENCES:}

Закон України «Про зайнятість населення» // Голос України. - 18.08.2012. - № 153-154.

Державне регулювання економіки: Навчальний посіб./ С.М. Чистов, А.С. Никифоров та ін. - Вид. 2-ге, доопрацьоване і доповнене. - К.: КНЕУ, 2005. - 440c.

Держсавне регулювання у ринковій економіuі / А. Н. Ластовецький/ Підприємництво, господарство і право/ Київ - 2003. - № 6. - С. 246.

Маршавін Ю.М. Державна служба зайнятості як складова системи держсавного управління в Україні: функиії та організаиійна структура: Навч.-метод. розробка. - К.: ІПК ДСЗУ, 2010. - 26 с.

Черниш Н. Соиіологія: Курс лекцій. - Львів: ЛБА, 1998. - 362 с.

Энииклопедический соииологический словарь /Под общ. ред. Г.В. Осипова. - М., 1995. - 939 с.

Global Employment Trends for Youth 2012 (May 2012), International labour Office, Geneva: ILO, 2012. - p.57.

WEB - портал Верховної Ради України // http://rada.gov.ua. - 2012. - 20 жовтня.

WEB - портал Державної служби зайнятості України // http://dcz.gov.ua. - 2012. - 30 листопада.

WEB - портал газети “Урядовий кур'єр” - щоденного видання центральних органів виконавчої влади України // http://www.ukurier.gov.ua. - 2012. - 30 листопада.

WEB - портал "Вікіпедія" // http://uk.wikipedia.org/wiki. - 2012. - 30 листопада.

WEB - портал “Інформаційне агентство "Українські Новини” // http://ukranews.com. - 2012. - 30 листопада. 